\title{
Pensononowoor
}

2021, vol. 85, 117-126

https://doi.org/10.12657/denbio.085.011

\author{
Vinod Prasad Khanduri*, Kewat Sanjay Kumar, \\ Chandra Mohan Sharma, Manoj Kumar Riyal, Kalpataru Kar, \\ Bhupendra Singh, Arun Sukumaran
}

\section{Passerine birds supporting cross pollination in Erythrina stricta Roxb.}

Received: 25 December 2020; Accepted: 11 May 2021

\begin{abstract}
Erythina stricta is an ecologically important tree species in the rainforests of India and its nectar within the flowers contributes to birds' diet and survival. Reports on the pollination of this species have not been published so far. We therefore explore the reproductive system of this tree species which has great significance to its ecosystem. Birds have an important role in the reproduction of trees through pollination particularly in tropical areas where reproductive success mostly depends on animal pollinator interactions. Study of visitation and nectar feeding behaviour of birds alongwith breeding system assessment of Erythina stricta.

Birds visiting and foraging behaviour was observed during Erythrina stricta flowering season in an indian tropical rainforest. Reproductive system was assessed through controlled pollination experiments.

Thirteen bird species were recorded visiting and foraging nectar from the flowers of Erythrina stricta. The maximum numbers of visits recorded were from the Red-vented Bulbul (Pycnonotus cafer, Pycnonotidae). The nectar feeding birds were, either (i) potential pollinator with long bills (e.g. Pycnonotus spp., Chloropsis aurifrons, and Dicrurus spp.) or (ii) nectar robbers with comparatively shorter bills (e.g. Zosterops palpebrosa, Stachyris ruficeps, Macronous gularis, Heterophasia glaciris). Controlled pollination experiments revealed high degree of cross pollination (xenogamy) and self-incompatibility in E. stricta.

Birds were more frequent in early mornings and their foraging activity was also observed during evening hours; the frequency however, declined with respect to nectar availability. Long corolla tubes of E. stricta could restrict access to nectar collecting bees.
\end{abstract}

Keywords: Ornithophily, pollination, mating system, geitonogamy, pollen grains

Addresses: V. P. Khanduri, C. M. Sharma, M. K. Riyal, B. Singh, A. Sukumaran, Department of Forestry, College of Forestry, VCSG Uttarakhand University of Horticulture and Forestry, Ranichauri, Tehri Garhwal - 249199 (Uttarakhand), India, e-mail: khandurivp@yahoo.com, sharmacmin@gmail.com, manoj.riyal@gmail.com, butola_bs@yahoo.co.in, arunsukumaranpn@gmail.com;

(1) VPK https://orcid.org/0000-0002-3858-7121, () CMS https://orcid.org/0000-0003-1553-0082,

(1) MKR https://orcid.org/0000-0003-0318-6341, (1) BS https://orcid.org/0000-0002-8705-2959,

(1) AS https://orcid.org/0000-0001-7805-5712

K. S. Kumar, K. Kar, Department of Forestry, Mizoram University, Aizawl (Mizoram), India,

e-mail: kewatsanjay@gmail.com, kalpatarukar11@gmail.com;

(D) KSK https://orcid.org/0000-0003-2951-1835, (1) KK https://orcid.org/0000-0001-7137-9837

Current address: A. Sukumaran, State Farming Corporation of Kerala, Chithalvetty Estate, Kalanjoor

Kollam, Kerala, India

*Corresponding author 


\section{Introduction}

Plant-pollinator interactions have distinct evolutionary history (Mitchell et al, 2009) in tropical forests (Bawa, 1990; Feinsinger, 1978). Birds play a significant role in tree reproduction through pollination success in tropical forests, however their role in pollination is documented (Morton, 1979; Ragusa-Netto, 2002; Mendonca \& Anjos, 2006; Rangaiah et al., 2004; Raju \& Rao, 2004; Silva et al., 2020). About 98-99\% of plant species are animal pollinated in tropical rain forests (Bawa, 1990; Fleming \& Muchhala, 2008; Prado et al., 2017). Specialized interactions between flowers and bird pollinators ascertain pollen transfer among individuals in the population and gene flow among populations, promoting cross pollination and variability (Anderson et al., 2005; Liu et al., 2013). The avian community plays a vital role in biological conservation (Franklin, 1993; Kati \& Sekercioğlu, 2006) and maintaining ecological balance through pollination and seed dispersal (Tews et al., 2004; Scaccabarozzi et al., 2020).

Erythrina (Fabaceae) is a pantropical genus comprised of 112 species distributed across tropical regions of the world (Krukoff \& Barneby, 1974). Out of these, at least 42 old world species and 15 new world species could be visited and pollinated by perching birds of several families of the order Passeriformes (Singh, 1929; Ali, 1932). In addition to passerines, more recent studies show Psittaciforms as important pollinators of Erythrina spp. (Cotton, 2001; Ragusa-Netto, 2002; Blanco et al., 2015; Silva et al., 2020). About 55 of the new world species could be pollinated by several hovering humming birds of the family Trochilidae (Toledo, 1974). The information on floral visitors of Erythrina stricta is not available so far. Therefore, this study aims to establish the: (i) Pattern of bird visits of Erythrina stricta (ii) Nectar feeding behavior of birds, (iii) How the morphological features of the flowers and behavioural features of birds contributes to pollination? and (iv) Assessment of breeding system following controlled pollination.

\section{Materials and methods}

The study was conducted in a tropical mixed semi deciduous natural forest of Bethlehem Vengthlang located in the district of district of Aizawl, Mizoram state in north-eastern hill region (NEH), India during the flowering season of the years 2010 and 2011. The study site was located at $23^{\circ} 43^{\prime} 47.5^{\prime \prime} \mathrm{N}$ latitude and $92^{\circ} 43^{\prime} 53.5^{\prime \prime} E$ longitude with an altitude of $900 \mathrm{~m}$ asl. Average annual rainfall in the study area over the last five years was $2100 \mathrm{~mm}$. The forest was heterogeneous and dominated by the trees species such as
Anthocephalus cadamba, Gmelina arborea, Schima wallichii, Calicarpa arborea, Erythrina stricta and Castenopsis spp.

Mizoram state has $90 \%$ of its area under forest cover (SFR, 2013). Forest types are mainly tropical wet evergreen, tropical semi evergreen, montane sub tropical and bamboo. Mizoram is a part of the Indo-Burma hot-spot, the zone is known for its unique, endemic and highly rich biological diversity. Over 70 species of passerine birds recognized as potential pollinators are also listed by IUCN as threatened, endangered or probably extinct (Nabhan, 1996). Mizoram is also part of the Endemic Bird Rich Area (EBRA) in eastern Himalaya, which is specified by BirdLife International (BLI). The region is highly significant for bird conservation priority because it contains habitats of restricted endemic bird species.

Twenty trees of Erythrina stricta were selected randomly over the whole population having profuse flowering and ample visibility and accessibility to determine the bird pollinators and their visitation rates. The selected trees were at least $50 \mathrm{~m}$ apart from one to another. Counting of visiting bird species and their frequencies were observed on these selected trees of Erythrina stricta over the entire flowering period. Observations of different birds visiting to the selected trees was done during two flowering seasons (February-March 2010 and 2011) which encompasses approximately 40 field days with $6-8$ hours/day recording. Observations were made in 2 observation blocks (i) 0600 to $1100 \mathrm{hrs}$ and (ii) 1500 to $1700 \mathrm{hrs}$. The selected observation blocks were worked out as per highest foraging activity of the birds. The frequency of the bird pollinators was assessed in terms of visits/ branch/day. Only bird floral visitors were included, which were observed with binocular, camera and also directly when they were specially found foraging on the flower. The mode of approach, landing, probing behaviour with bill while perching, contact with reproductive organs to facilitate pollination, climbing on flowers and inflorescences, damage to flowers (if any) of visiting bird species on each selected tree were meticulously observed and recorded. Flower handling time was recorded using digital stopwatch. Birds were classified in to two flowering categories as per their foraging activity and behaviour as; (a) Potential pollinators, when the bird touched the reproductive parts of flowers while foraging, and (b) Nectar robbers, when the birds probed the nectar by holes bitten in the corollas. The relative frequency of visits of each bird species was determined as the number of visits performed by that species in relation to the total number of visits recorded and represented in percentage. Photographs of birds, while foraging the inflorescences were used for analysis and evaluation of bird visiting behaviour. Flower corolla morphometrics of Erythrina stricta were measured by choosing randomly fifty flowers from five different trees. 
The volume of nectar available to pollinators in the replenishment phase was estimated as per method of Castellanos (2002). The flowers $(n=10)$ were randomly bagged in polyethene bags before anthesis. After removing the first crop of nectar, one set of these flowers was subjected to hourly extraction of nectar $(0800 \mathrm{~h}$ to $1400 \mathrm{~h})$ with calibrated micropipette. For a total of $6 \mathrm{~h}$ duration the flowers were bagged after each extraction. However, for control, all the available nectar was collected after $6 \mathrm{~h}$ from other sets of flowers $(n=10)$. The cumulative quantity of nectar replenished was finally noted.

Ten trees in the population were selected randomly to evaluate the mating system of the E. stricta. After analyzing the peak receptivity of stigma with hydrogen peroxide for peroxidase test (Dafni et al., 2005), the following pollination treatments were applied randomly; (1) Apomixis ( $\mathrm{n}=20$ flowers), for which flowers were emasculated and bagged with polyethene bags; (2) Autogamous self pollination ( $\mathrm{n}=20$ flowers), for which flowers were bagged one day before anthesis without emasculation; (3) Hand self pollination ( $\mathrm{n}=20$ flowers), for which the self-stigma was dusted with pollen from same flower and bagged with polythene bags; (4) Geitonogamy (by hand) ( $\mathrm{n}=20$ flowers), for which flowers were pollinated with pollen from anthers of different flowers from same trees and bagged with polythene bags; and (5) Hand cross-pollination i.e., xenogamy ( $\mathrm{n}=20$ flowers), for which flowers were emasculated, bagged and pollinated with pollen grains from different trees and re-bagged. Non bagged and open pollinated $(\mathrm{n}=20)$ flowers, were also analyzed and considered as control. Fruit set among (i) handselfed and hand cross-treatments and (ii) open pollinated and hand-cross-treatments were compared. To know the pattern of variability between these treatments, a Chi-square analysis was performed (Zar, 1999). An indirect measure of self-incompatibility was estimated by dividing the average fruit set after hand self-pollination by the average fruit set after hand cross pollination (Zapata \& Arroyo, 1978; Lloyd \& Schoen, 1992). The resultant values of index reflected the possibilities as (i) $>1=$ self-compatible; (ii) $>0.2$ and $<1=$ partially self-incompatible; (iii) $<0.2=$ mostly self-incompatible; and (iv) 0.0 = completely self-incompatible (Zapata \& Arroyo, 1978). The effects of time of the day on the foraging frequency of the birds were examined using ANOVA with time as a fixed effect (independent variables). Counts were log-transformed in order to improve normality of residuals and to reduce heteroscedasticity (Sokal \& Rohlf, 1995). ANOVA was performed using the super ANOVA statistical package (Abacus Concepts, 1998). A Pearson correlation was also analysed between time of the day and nectar production.

\section{Results}

The Erythrina stricta remains leafless during flowering period, which occurs during second week of February to the third week of March. Synchronous flowering within and among the individuals in a population was observed with the simultaneous

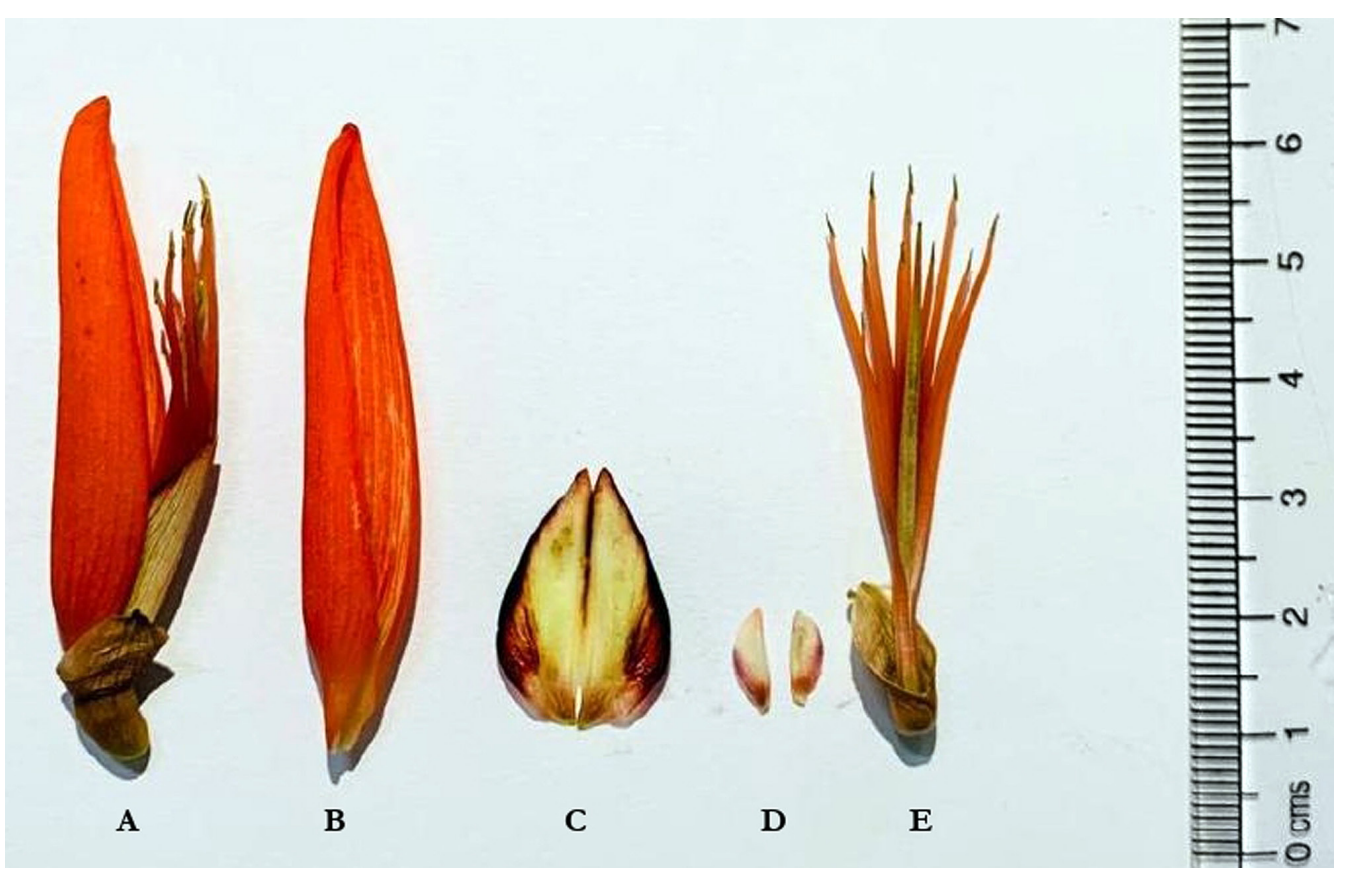

Fig. 1. Flower parts of Erythrina stricta

A - whole flower, B - standard petal, C - keel petals, D - wing petals, E - stamens and pistil. 


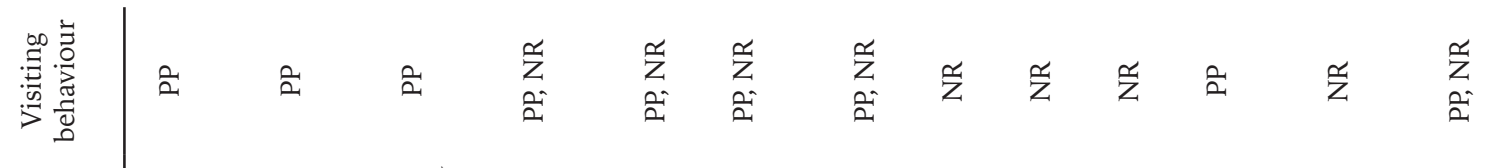

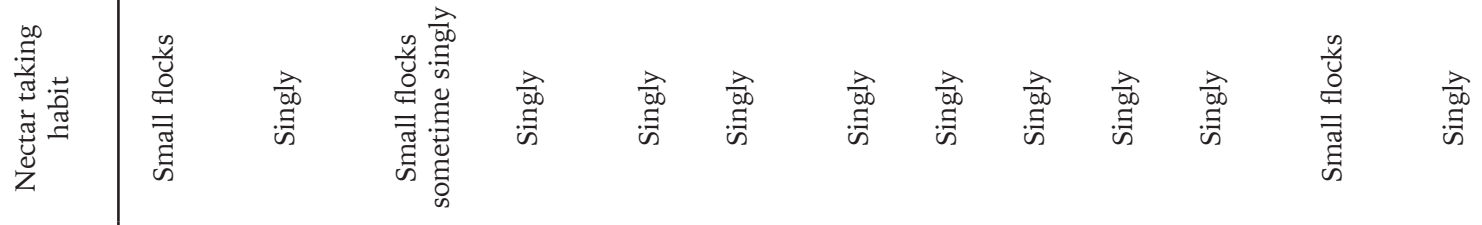

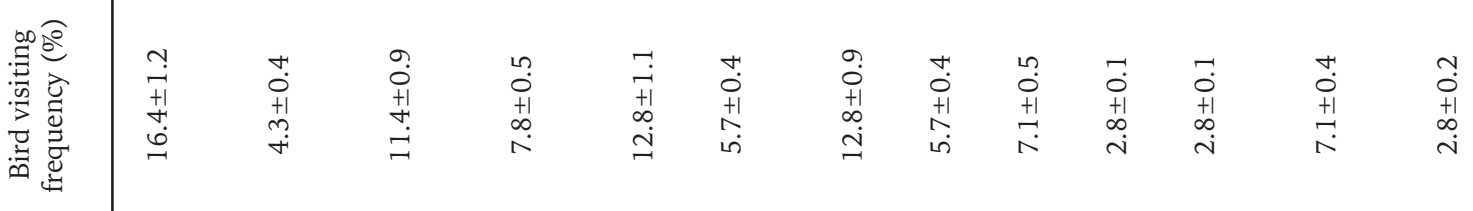

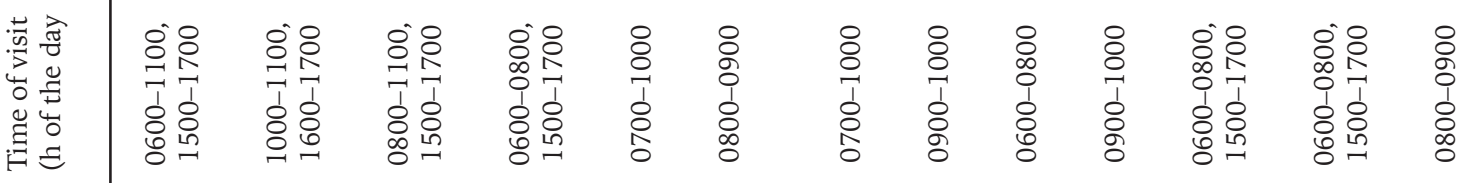

案 希

這兘

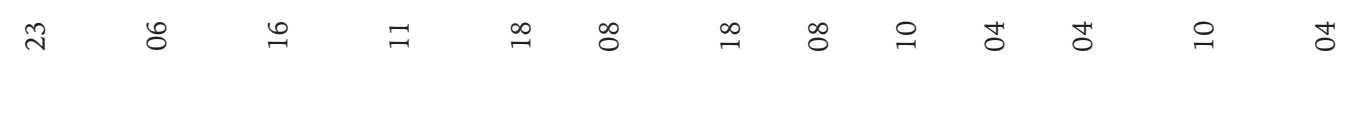

宅.

芦高

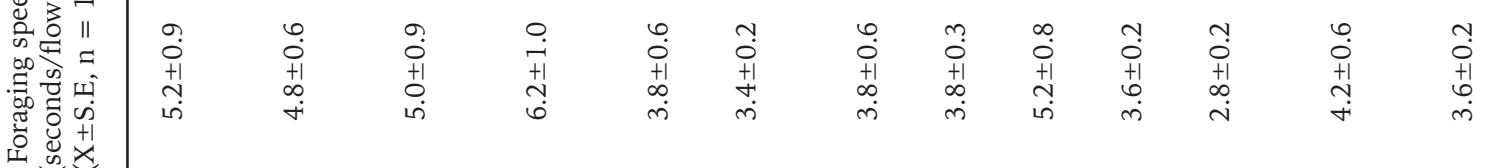

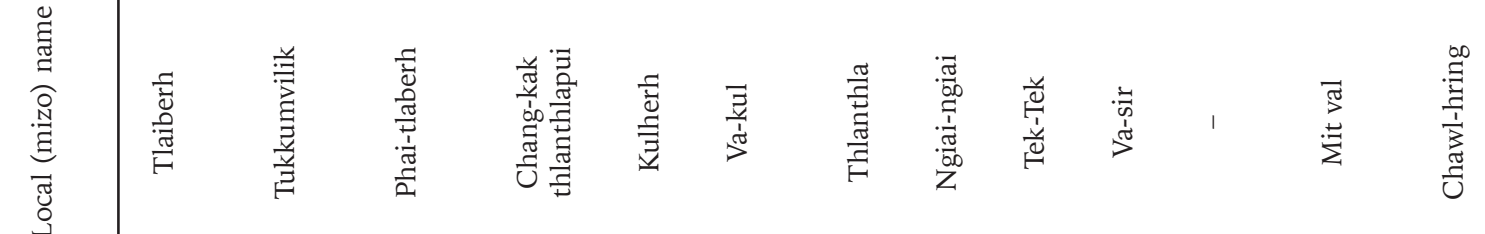

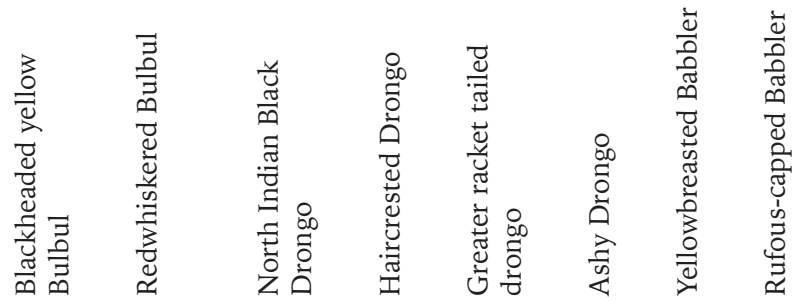

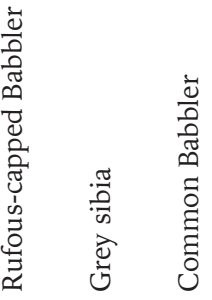


blooming of flowers from basal to the apical tip portion within an inflorescence. The flowers are arranged in terminal racemes, $15-18 \mathrm{~cm}$ long and crowded at the distal end of branchlets. Flowers are bisexual, Papilionaceous corolla with one well-developed bright red standard petal of $5.2 \times 2.2 \mathrm{~cm}$, two greenish-red keel petals of $2.3 \times 1.4 \mathrm{~cm}$; two poorly developed very light-red wing petals of $0.8 \times 0.4 \mathrm{~cm}$. The keel petals form a carinal-like structure and hold nectar inside. Stamens 10, monadelphous, usually bend upwards facing the standard petal. Ovary inferior and was enclosed by the staminal sheath, the style comes out through the sheath and ends with a minute stigma (Fig. 1).

During the daytime, from 0600 to 1100 and 1500 $1700 \mathrm{hrs}$, a wide range of birds visited the flowers of E. stricta to collect nectar (Table 1). In total thirteen bird species were recorded visiting and foraging nectar in this species. The maximum number of visits of E. stricta flowers were recorded for the red-vented Bulbul Pycnonotus cafer (Pycnonotidae) (Fig. 2I, $\mathrm{J})$, followed by the red whiskered Bulbul Pycnonotus jocosus, the indian white eye Zosterops palpebrosa (Fig. 2G), and Goldenfronted chloropsis Chloropsis aurifrons (Fig. 2C, D).

All the members of family Pycnonotidae (Pycnonotus cafer, Pycnonotus jocosus, Pycnonotus melanicterus flaviventris), and Chloropsis aurifrons foraged legitimately the flowers for deep seated nectar and were able to bring about pollen dispersal and transfer in E stricta are categorized as potential pollinators (PP) (Table 1). On the other hand Zosterops palpebrosa, Stachyris ruficeps, Macronous gularis and Heterophasia gracilis precluding access to nectar tend to rob the nectar in $E$. stricta. They generally pierce with beak the sides of the corolla tube to steal nectar and are considered as nectar robbers (NR). Chloropsis aurifrons also steal some nectar by piercing floral tube.

Members of family Dicruridae (Dicrurus leucophaeus, and Dicrurus paradiseus) were robust forager of flowers for nectar and acted as potential pollinator because they legitimately contacted stamens and stigmas with their beaks, heads and body, therefore affecting pollination in E. stricta. Nevertheless, they

Table 2. Resumption of nectar secretion following nectar removal in Erythrina stricta

\begin{tabular}{cc}
\hline Time $(\mathrm{h})$ & $\begin{array}{c}\text { Nectar volume }(\mu \mathrm{L}) / \text { flower } \\
(\mathrm{X} \pm \mathrm{S} . \mathrm{E}, \mathrm{n}=10)\end{array}$ \\
\hline 0800 & $211 \pm 22$ \\
0900 & $122 \pm 15$ \\
1000 & $45 \pm 6$ \\
1100 & $23 \pm 3$ \\
1200 & $12 \pm 2$ \\
1300 & $7 \pm 1$ \\
1400 & $5 \pm 1$ \\
Control (single extraction after 06 h) & $265 \pm 28$ \\
\hline
\end{tabular}

collected nectar very aggressively, which also lead to damage and removal of flowers.

The foraging pattern of foragers was twice in a day with forenoon and evening hours with more foraging activity during forenoon hours (0600 to $1100 \mathrm{hrs)}$ ). Pycnonotus spp. and Dicrurus spp. made more visits to the flowers than any other bird species. Different bird species were found foraging simultaneously on the flowers of same tree. The photographs of the important visiting birds have been presented in Fig. 2A-J, which clearly shows the interaction of bird's beak and body parts with the reproductive parts of the flowers.

Nectar secretion was recorded from anthesis onwards. Nectar production in the flowers of E. stricta begins at $0500 \mathrm{~h}$ and at the time of anthesis around $0545 \mathrm{~h}$ the flowers were full with their first crop of nectar. The average amount of nectar available to floral visitors was $225 \pm 22 \mu \mathrm{L}$ (means \pm standard error) and after first round of nectar harvesting, it declined to $51 \pm 7 \mu \mathrm{L}$ (Table 2). Thus, an average amount of nectar consumed by floral visitors from flowers $(\mathrm{n}=10)$ in first round is approximately $174 \mu \mathrm{L}$. The cumulative quantity of nectar produced after $6 \mathrm{~h}$ in a single harvest is $265 \pm 28 \mu \mathrm{L}$, which is far below than the cumulative quantity of replenished nectar from multiple harvests $(425 \mu \mathrm{L})$. This indicates that if the nectar is not removed from the flower, it does not produce significant amount of additional nectar in the remaining period. The production of nectar volume in E stricta was recorded to be maximum in the morning up to $0900 \mathrm{~h}$, which was significantly correlated ( $\mathrm{p}<0.0001)$ with timing of different birds visit in a day. The nectar production decreased sharply from $0900 \mathrm{~h}$ onwards and the difference between two visits $(0800$ and $1000 \mathrm{~h})$ was $78.7 \%$. The lowest nectar volume recorded was $5 \pm 0.66 \mu \mathrm{L} /$ flower at $1400 \mathrm{~h}$ (Table 2). There was significant effect of time $(\mathrm{F}=1.54, \mathrm{df}=6, \mathrm{p}=0.003)$ on foraging frequency of birds in Erythrina stricta. Strong significant $(p<0.001)$ relationship was also apparent between timing of bird visits and nectar production, indicating that nectar production and time of the day plays a vital role for visiting different bird species in E. stricta.

The controlled pollination revealed that there was no fruit and seed set in autogamous self pollinated

Table 3. Mating system studies in Erythrina stricta

\begin{tabular}{lcc}
\hline \multicolumn{1}{c}{ Treatments } & $\begin{array}{c}\text { \% fruit set } \\
(\mathrm{X} \pm \text { S.E } \mathrm{n}=20)\end{array}$ & $\begin{array}{c}\text { \% seed set } \\
(\mathrm{X} \pm \mathrm{S} . \mathrm{E}, \mathrm{n}=20)\end{array}$ \\
\hline Apomixis & 0.0 & 0.0 \\
Autogamous self-pollination & 0.0 & 0.0 \\
Hand self-pollination & $3.6 \pm 0.5$ & $18.4 \pm 2.3$ \\
Geitonogamy (by hand) & $6.6 \pm 1.3$ & $50.4 \pm 2.2$ \\
Hand cross-pollination & $52.4 \pm 4.2$ & $84.4 \pm 3.3$ \\
Open pollination (control) & $39.1 \pm 3.6$ & $70.4 \pm 6.3$ \\
\hline
\end{tabular}


Vinod Prasad Khanduri et al.
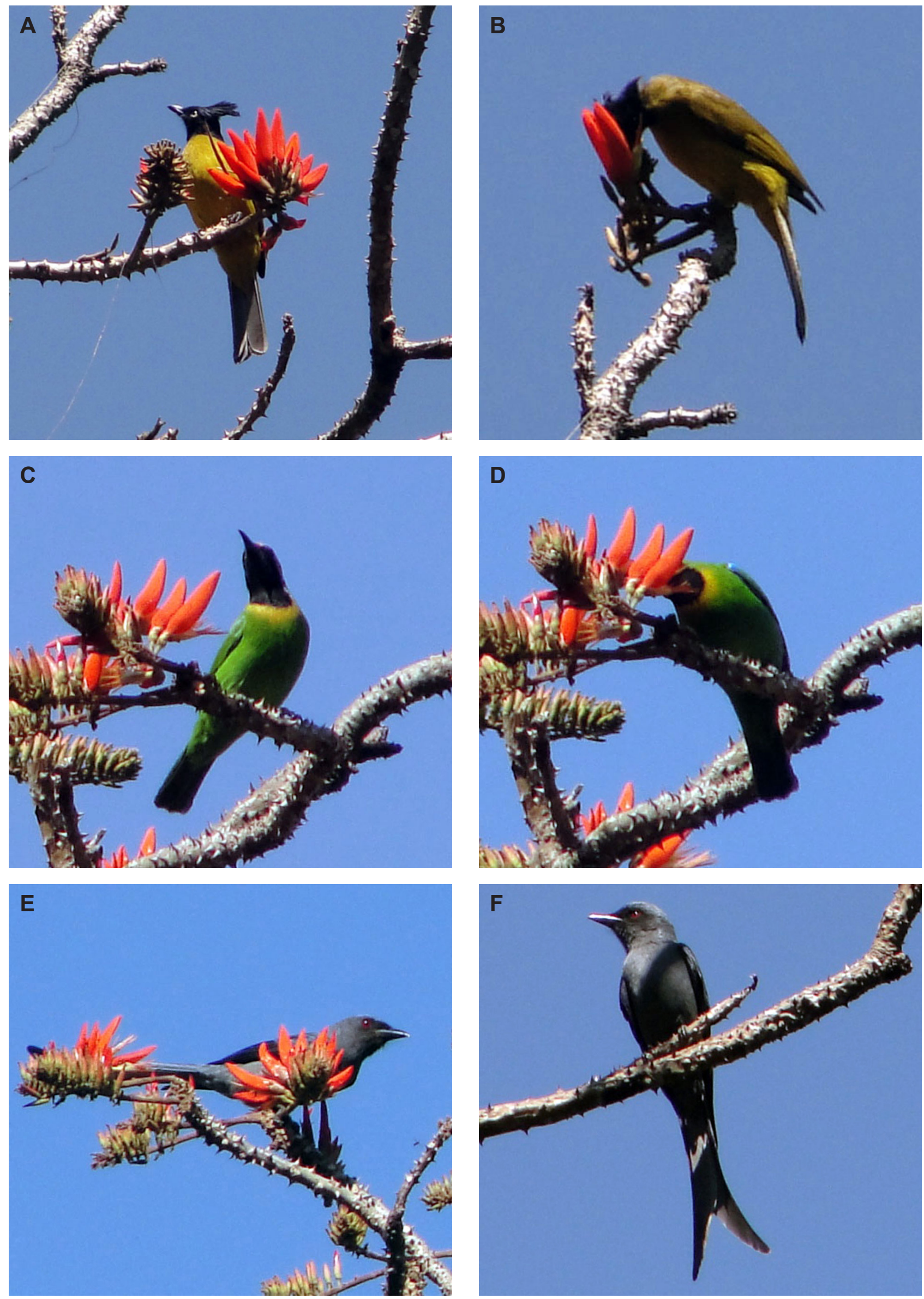

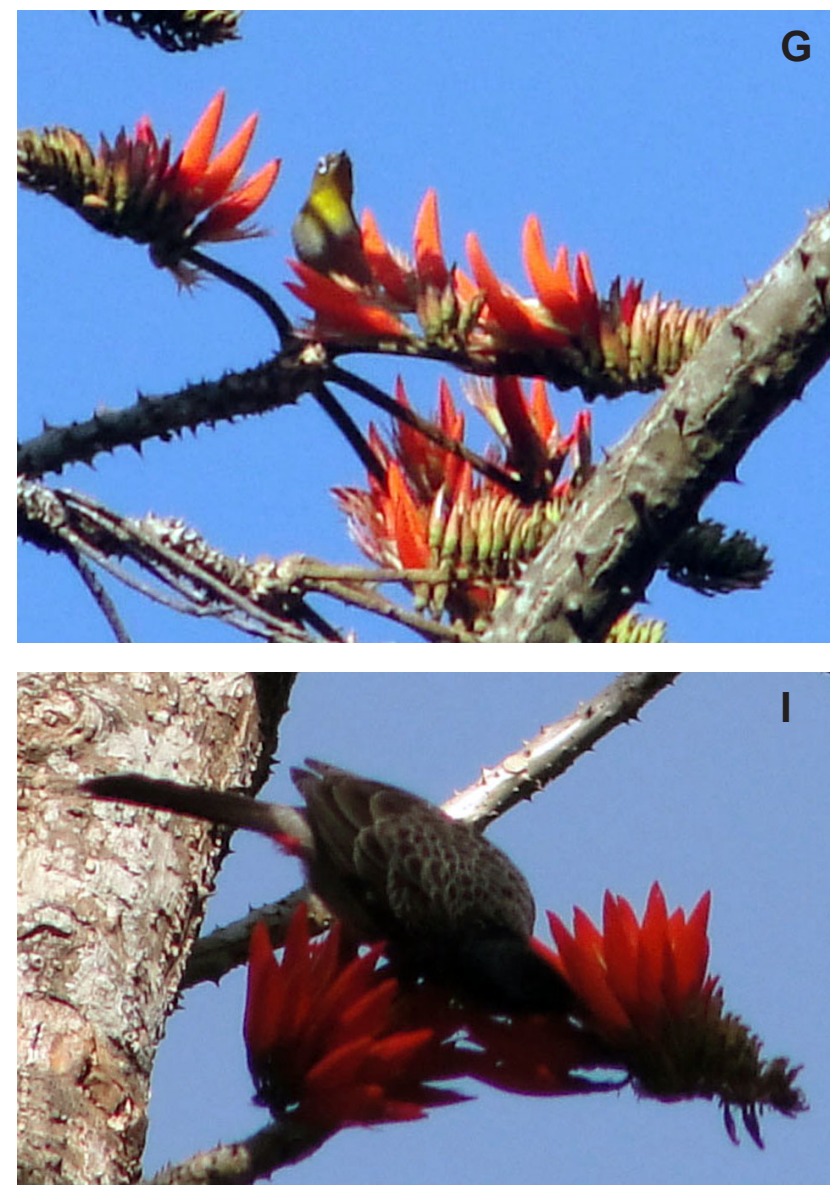
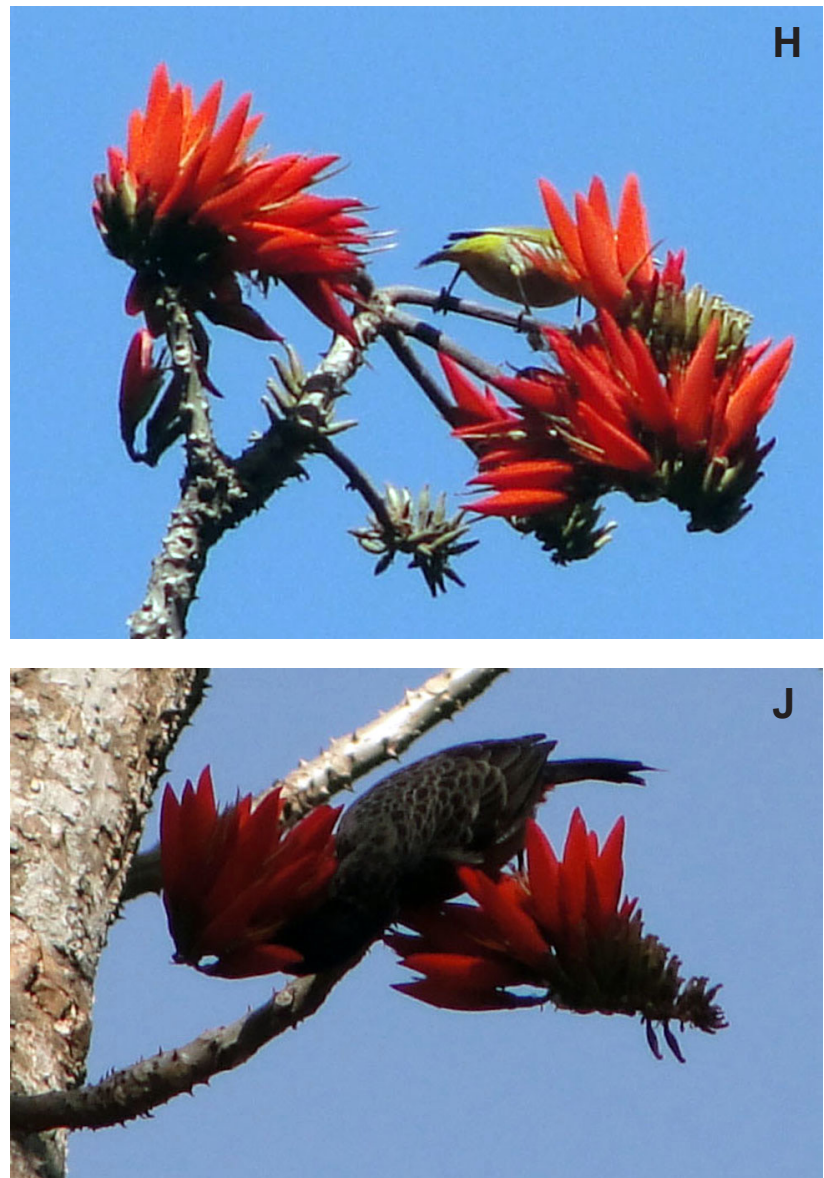

Fig. 2. Different pollinators of Erythrina stricta

A, B - Black-crested Bulbul (Pycnonotus melanicterus flaviventris) foraging nectar; C, D - Golden-fronted Leafbird (Chloropsis aurifrons) foraging nectar; E, F - Ashy Drongo (Dicrurus leucophaeus); G - Indian white-eye (Zosterops palpebrosa); H - Yellowbreasted Babbler (Macronous gularis); I, J - Red-vented Bulbul (Pycnonotus cafer).

flowers, however, meager fruit set $(3.6 \pm 0.56)$ was recorded after hand self pollination. Flowers bagged to ascertain apomixes in E. stricta failed to set fruits. Geitonogamy (by hand) also revealed low fruit set $(6.6 \pm 1.26)$. Hand cross-pollinated flowers (xenogamy) produced high fruit $(52.4 \pm 4.24)$ and seed $(84.4 \pm 3.28)$ sets. There were significant differences between hand self and hand cross treatments $\left(\mathrm{X}^{2}=45.6, P<0.0001\right)$ and between open pollinated and hand cross treatments $\left(\mathrm{X}^{2}=9.8, P<0.041\right)$. Manual cross pollination treatment was more successful than manual self-pollination and open pollination (Table 3). The index of self-incompatibility (ISI) value was estimated to be 0.068 . Thus, E. stricta is mostly self-incompatible with a high level of out crossing (xenogamy).

\section{Discussion}

Erythrina stricta is an ecologically specialized species that shows floral orientation in such a manner that it is very helpful for perching birds to feed on the nectar of flowers, which leads to deposition of pollens on beak and body parts of birds and pollen transfer takes place. Birds made frequent visits between trees in search of nectar and such foraging behaviour supports cross-pollination. Nevertheless, about $7 \%$ pod set was observed in geitonogamy (inter flower selfing) experiment and the birds may also be responsible for geitonogamy by foraging nectar from flowers of different inflorescences on same branch. This was observed in the case of Red-vented Bulbul (Pycnonotus cafer) which foraged nectar in the first attempt from flowers of right inflorescence (Fig 2I) and thereafter from left inflorescence (Fig 2J).

Inflorescences axis of E. stricta provides excellent primary and secondary perches for birds visiting the flowers. The main features present in E. stricta associated with ornithophily are: (1) flowers are generally upwardly oriented and have exposed stamens and stigma covered by broad keel, and (2) dense floral clustering in inflorescences is commonly linked to pollination by perching birds (Liu et al., 2013). When nectarivorous birds feed on nectar, pollen grains get deposited on the head or breast, helping pollen dispersal between flowers (Cruden \& Toledo, 1977; Mitchell et al., 2009). Portions of head, bills and breast of 
passerine birds make a precise, regular and repeated contact with the floral parts (particularly stamens and stigma of the flowers). The long tube of $1.7 \mathrm{~cm}$ corollas of E. stricta seem to be adapted to pollination by long billed passerine birds and hummingbirds, as found for other Erythrina species with similar floral traits (Neill, 1987). Flowers visited by these birds are overwhelmingly tubular in shape (Fleming \& Muchhala, 2008). Pollen grains were dusted reasonably on the crowns and heads of bird species, when they contacted with dehisced anthers and receptive stigmas.

Passerines nectarivorous birds in the present study were sometimes observed to forage in groups for which the birds require sufficient floral resources to meet their energy requirements. Nectar production in one or few trees of $E$. stricta shall deplete fast and flock of passerine birds could quickly exhaust the nectar which compelled the birds to make frequent visits to different trees, thus facilitated cross-pollination that was verified by the pollination experiments (a self-incompatible species). In cross pollinated trees species, natural fruit set and plant fitness depends on the frequency, availability and efficacy of pollinators to transfer compatible pollens. A variety of bird's species visited E. stricta on different conspecific trees during flowering phase for floral nectar and completed the pollination process through pollen dispersal. The way bird probed nectars of E. stricta is a function of morphological features particularly the bill lengths and approaching behaviours of birds (Almeida \& Aves, 2003). The behavioural attributes of the birds and characteristics of flowers have determined the role of floral visitors as potential pollinator (Kevan, 1999). The birds tend to visit twice in the day, i.e. morning and evening hours of the day (birds deplete the nectar first in the morning hours then come back when nectar is replenished). This pattern of bird visitation was the special features of E. stricta, which is not reported in other Erythrina species so far. This pattern of visit would be due to continuous production of nectar during different hour of the day, though the amount was decreasing with that of morning secretion, which would be accumulated enough for the needs of birds during night time. Therefore, the degree of feeding decreases from morning to evening hours. It is also important to point out that E. stricta bears flowers in the dry season and contribute to a valuable nectar source for the birds. Nectar thieving normally seems due to mismatch between floral visitors and floral architecture (Inouye, 1983). The distinction between nectar thieves and robbers is important because the latter may have a greater effect in reducing the reproductive potential of the plant by damaging the sexual tissues and often destroying or removing the entire flower. Relatively few studies have addressed the importance of short-billed opportunistic birds as pollinators (Gill et al., 1998; Raju
\& Rao, 2004; Rangaiah et al., 2004) although they have often been recorded worldwide as nectar robbers (Franklin, 1999; Franklin \& Noske, 1999).

Amount of nectar per flower remained fairly constant throughout the day in the bagged flowers, indicating that the nectar secretion ceases after maximum volume has been reached (Neil, 1987). Removal of nectars by bird species might cause the replenishment of secretion in E. stricta, as was observed during repeated sampling of same flowers along the day. Similar trends were also observed in Erythrina speciosa (Mendonca \& Anjos, 2006) and Erythrina variegata (Rangaiah et al., 2004). Quantity of nectar secretion in flower along with time was ecologically significant because pollinators were likely to make foraging decision based on encountered reward from standing crop (Mc dade \& Weers 2004; Pyke, 1991).

\section{Conclusions}

E. stricta is a mostly self-incompatible outcrossed species which requires pollinator services for reproductive success. Moreover, the morning and evening hrs pattern of bird visitation in E. stricta is of great interest which would augment the reproductive success in E. stricta, i.e. $39 \%$ as most of the Erythrina species are reported to have low fruit set $(<5 \%$, Etcheverry \& Alemán, 2005) following natural pollination. The present study appears to be the first to document the breeding systems and identify the primary pollinators of E. stricta.

\section{Funding}

This research was supported by the Council of Scientific and Industrial Research (CSIR), Government of India, New Delhi, vide its project No. 38(1186)/08/EMR-II.

\section{Acknowledgements}

The authors are thankful to all the four anonymous Reviewers of the earlier draft of this manuscript for reviewing the manuscript deeply and raising valuable comments, suggestions and corrections which has immensely improved the quality of the manuscript.

\section{References}

Abacus Concepts (1998) Super anova. Abacus Concepts, Berkeley.

Ali SA (1932) Flower-birds and birds-flowers in India. Journal of Bombay Natural History Society 35: 573-605. 
Anderson B, Cole WW \& Barrett SCH (2005) Specialized bird perch aids cross pollination. Nature 435: 41-42.

Bawa KS (1990) Plant-pollinator interactions in tropical rain forests. Annual Review of Ecology and Systematics 21: 399-422.

Blanco G, Hiraldo F, Rojas A, Dénes FV \& Tella JL (2015) Parrots as key multilinkers in ecosystem structure and functioning. Ecology and Evolution 18: 4141-4160. doi:10.1002/ece3.1663.

Castellanos MC, Wilson P \& Thomson JD (2002) Dynamic nectar replenishment in flowers of Penstemon (Scrophulariaceae). American Journal of Botany 89: 111-118.

Cotton PA (2001) The behavior and interactions of birds visiting Erythrina fusca flowers in the Colombian Amazon. Biotropica 33: 662-669. doi:10.1646/0006-3606(2001)033[0662:TBAIOB]2.0.CO;2.

Cruden RW \& Toledo VM (1977) Oriole pollination of Erythrina breviflora (Leguminosae): Evidence for a polytypic view of ornithophily. Plant Systematics and Evolution 126: 393-403.

Dafni A, Kevan PG \& Husband BC (2005) Practical pollination biology. Enviroquest Ltd, Ontario.

Etcheverry AV \& Alemán CET (2005) Reproductive biology of Erythrina falcata (Fabaceae: Papilionoideae). Biotropica 37: 54-63. doi:10.1111/ j.1744-7429.2005.03053.x.

Feinsinger P (1978) Ecological interactions between plants and hummingbirds in a successional tropical community. Ecological Monographs 48: 269287. doi: $10.2307 / 2937231$.

Fleming TH \& Muchhala N (2008) Nectar-feeding bird and bat niches in two worlds: pantropical comparisons of vertebrate pollination systems. Journal of Biogeography 35: 764-780. doi:10.1111/j.1365-2699.2007.01833.x.

Franklin DC \& Noske RA (1999) Birds and nectar in a monsoonal woodland: correlations at three spatio-temporal scales. Emu 99: 15-28. doi:10.1071/ MU99003.

Franklin DC (1999) Opportunistic nectarivory: an annual dry season phenomenon among birds in monsoonal Northern Australia. Emu 99: 135141. doi:10.1071/MU99016.

Franklin JF (1993) Preserving biodiversity: Species, ecosystems, or landscapes? Ecological Applications 3: 202-205. doi:10.2307/1941820.

Gill GE, Fowler RT \& Mori SA (1998) Pollination biology of Symphonia globulifera (Clusiaceae) in central French Guinea. Biotropica 30: 139-144.

Inouye DW (1983) The ecology of nectar robbing: The biology of nectaries (ed. by B Bentley \& T Elias) Columbia University Press, New York, USA, pp. 153-174.
Kati VI \& Sekercioğlu CH (2006) Diversity, ecological structure, and conservation of the landbird community of Dadia reserve, Greece. Diversity and Distribution 12: 620-629. doi:10.1111/ j.1366-9516.2006.00288.x.

Kevan PG (1999) Pollinators as bioindicators of the state of the environment: species, activity and diversity. Agriculture, Ecosystems and Environment 74: 373-393. doi:10.1016/S01678809 (99)00044-4.

Krukoff BA \& Barnbey RC (1974) Conspectus of species of the genus Erythrina. Lloyodia 37: 332-459.

Kumar HD (2000) Plant animal interactions. Affiliated East-West press Pvt limited, New Delhi, India.

Liu ZJ, Chen LJ, Liu KW, Li LQ, Rao WH, Zhang YT, Tang GD \& Huang LQ (2013) Adding perches for cross-pollination ensures the reproduction of a self-incompatible orchid. PLoS ONE 8: e53695. doi:10.1371/journal.pone.0053695.

Lloyd DG \& Schoen DJ (1992) Self- and cross-fertilization in plants. I. Functional dimensions. International Journal of Plant Sciences 153: 358-369.

Mendonca LB \& Anjos LD (2006) Feeding behavior of hummingbirds and perching birds on Erythrina speciosa Andrews (Fabaceae) flowers in an urban area, Londrina, Parana, Brazil. Revista Brasileira de Zoologia 23: 42-49. doi:10.1590/S010181752006000100002 .

Mitchell RJ, Irwin RE, Flanagan RJ \& Karron JD (2009) Ecology and evolution of plant-pollinator interactions. Annals of Botany 103: 1355-1363. doi:10.1093/aob/mcp122.

Morton ES (1979) Effective pollination of Erythrina fusca by the orchard oriole (I. spurius): coevolved behavioral manipulation? Annals of the Missouri Botanical Garden 66: 482489. doi: $10.2307 / 2398840$.

Nabhan GP (1996) Global list of threatened vertebrate wildlife species serving as pollinators for crops and wild plants. Forgotten Pollinators Campaign, Arizona-Sonora Desert Museum, Tucson.

Neil DA (1987) Trapliners in the trees: hummingbird pollination of Erythrina Sect. Erythrina (Leguminosae: Papilionoideae). Annals of the Missouri Botanical Garden 74: 27-41. doi:10.2307/2399259.

Prado SG, Ngo HT, Florez JA \& Collazo JA (2017) Sampling bees in tropical forests and agroecosystems: a review. Journal of Insect Conservation 21: 753-770. doi:10.1007/s10841-017-0018-8.

Pyke GH (1991) What does it cost a plant to produce floral nectar? Nature 350: 58-59.

Ragusa-Netto J (2002) Exploitation of Erythrina dominguezii Hassl. (Fabaceae) nectar by perching birds in a dry forest in western Brazil. Brazilian Journal of Biology 62: 877-883. doi:10.1590/ S1519-69842002000500018. 
Raju AJS \& Rao SP (2004) Passerine bird pollination and fruiting behaviour in a dry season blooming tree species, Erythrina suberosa Roxb. (Fabaceae) in the Eastern Ghats forests, India. Ornithological Science 3: 139-144. doi:10.2326/osj.3.139.

Rangaiah K, Raju AJS \& Rao SP (2004) Passerine bird-pollination in the Indian coral tree, Erythrina variegate var. orientalis (Fabaceae). Current Science 87: 736-739.

Scaccabarozzi D, Dixon KW, Tomlinson S, Milne L, Bohman B, Phillips RD \& Cozzolino S (2020) Pronounced differences in visitation by potential pollinators to co-occurring species of Fabaceae in the Southwest Australian biodiversity hotspot. Botanical Journal of the Linnean Society 194: 308-325.

SFR (2013) India State of Forest Report. Forest Survey of India, Dehradun, India.

Silva PA, Silva LL \& Brito L (2020) Using bird-flower interactions to select native tree resources for urban afforestation: the case of Erythrina velutina.
Urban Forestry \& Urban Greening 51: 126677. doi:10.1016/j.ufug.2020.126677.

Singh TCN (1929) A preliminary note on the pollination of the coral tree (Erthrina indica, Lamk.). Journal of the Bombay Natural History Society 33: 460-462.

Sokal RR \& Rohlf FJ (1995) Biometry, 3rd ed. WH Freeman, San Francisco.

Tews J, Brose U, Grimm V, Tielborger K, Wichmann MC, Schwager M \& Jeltsch F (2004) Animal species diversity driven by habitat heterogeneity/ diversity: the importance of keystone structures. Journal of Biogeography 31: 79-92. doi:10.1046/ j.0305-0270.2003.00994.x.

Toledo VM (1974) Observations on the relationships between hummingbirds and Erythrina species. Lloyodia 37: 482-487

Zapata TR \& Arroyo MTK (1978) Plant reproductive ecology of a secondary deciduous tropical forest in Venezuela. Biotropica 10: 221-230.

Zar JH (1999) Biostatistical analysis. 4th. ed. Prentice Hall, Upper Saddle River, NJ, USA. 